\title{
The Role of Insulin, Insulin Growth Factor, and Insulin-Degrading Enzyme in Brain Aging and Alzheimer's Disease
}

\author{
Claude Messier and Kevin Teutenberg
}

School of Psychology, University of Ottawa, Ottawa, Ontario, Canada K1N 6N5

\begin{abstract}
Most brain insulin comes from the pancreas and is taken up by the brain by what appears to be a receptor-based carrier. Type 2 diabetes animal models associated with insulin resistance show reduced insulin brain uptake and content. Recent data point to changes in the insulin receptor cascade in obesity-related insulin resistance, suggesting that brain insulin receptors also become less sensitive to insulin, which could reduce synaptic plasticity. Insulin transport to the brain is reduced in aging and in some animal models of type 2 diabetes; brain insulin resistance may be present as well. Studies examining the effect of the hyperinsulinic clamp or intranasal insulin on cognitive function have found a small but consistent improvement in memory and changes in brain neuroelectric parameters in evoked brain potentials consistent with improved attention or memory processing. These effects appear to be due to raised brain insulin levels. Peripheral levels of Insulin Growth Factor-1 (IGF-I) are associated with glucose regulation and influence glucose disposal. There is some indication that reduced sensitivity to insulin or IGF-I in the brain, as observed in aging, obesity, and diabetes, decreases the clearance of $A \beta$ amyloid. Such a decrease
\end{abstract}

Reprint requests to: Dr. Claude Messier, School of Psychology, University of Ottawa, 145 Jean-Jacques Lussier, Room 352, Ottawa, Ontario Canada, K1N 6N5. e-mail: cmessier@uottawa.ca involves the insulin receptor cascade and can also increase amyloid toxicity. Insulin and IGF-I may modulate brain levels of insulin degrading enzyme, which would also lead to an accumulation of $A \beta$ amyloid.

\section{KEYWORDS}

literature review, diabetes, glucose regulation, hyperinsulinemia, impaired glucose tolerance, cognitive function. dementia, vascular disease, memory

\section{INTRODUCTION}

Over the last few years, there has been a reevaluation of the role of insulin and insulin growth factors in brain functions. This re-evaluation has been driven by a number of observations and hypotheses that encompass the control of feeding and adiposity, the impact of diabetes on the brain and more recently, the interactions among insulin, diabetes, Alzheimer's disease, and amyloid deposition. Several recent reviews have addressed the role of brain insulin in the control of metabolism and food intake (Gerozissis 2003. Porte et al., 2005). Among several recent reports that support such a role of insulin is the demonstration that mice with conditional knockout of insulin receptors in the brain are overweight, insulin resistant, and glucose intolerant (Bruning et al., 2000). Furthermore, blockade of hypothalamic 
insulin receptors by antisense oligonucleotides produced hyperphagia, insulin resistance, and weight increase (Obici et al., 2002). These examples clearly show that the brain insulin plays an important role in feeding, peripheral metabolism, and weight regulation. Recent evidence of a down-regulation of brain insulin receptors in obesity and diabetes suggest that insulin resistance may also involve the brain (Mielke, 2005).

The aim of this review is to put together various recent data that describe the possible role of insulin, insulin receptors, and insulin growth factors in learning and memory. The role of insulin-related peptides is examined in the context of aging, diabetes, and Alzheimer's disease The general hypotheses that are entertained in this review are that

1. type 2 diabetes and obesity lead to insulin resistance in the brain,

2. insulin resistance leads to cognitive impairments in older diabetic patients and

3. insulin resistance increase amyloid deposition in Alzheimer's disease patients.

We first examine what is known about insulin's access to the brain and the impact of diabetes on the transfer of insulin from blood to the brain. We then present a brief summary of the results of studies that examined the interactions between diabetes, aging, and brain with reference to recent reviews for an in-depth analysis of the neurocognitive deficits in type 2 diabetes (Awad et al., 2004; Messier, 2003; Messier et al., 2004). Following this, we review studies that have tested the ability of insulin to modulate brain functions with a particular attention to learning and memory. For an in-depth review of the role of insulin in metabolism, feeding, and weight control, the reader can consult several excellent reviews (Gerozissis 2003. Porte et al., 2005. Woods, et al., 2003). Because insulin and insulin growth factor 1 (IGF-I) partially share receptor activity and interact under certain circumstances, we briefly discuss several aspects of IGF-I in the adult and the aging brain. Finally, we examine the interaction of insulin and IGF-I with amyloid deposition and processing as a possible mechanism in the deleterious effect of diabetes on Alzheimer's disease progression. We now turn to the examination of the source of insulin in the brain.

\section{INSULIN TRANSPORT THROUGH THE BLOOD- BRAIN BARRIER}

As discussed by Banks (2004), the nature of insulin resistance in the brain remains unclear. In the periphery, most insulin resistance is associated with receptor or post-receptor effects in specific tissues. In the brain, insulin resistance can manifest itself through changes in brain insulin uptake and by changes in the insulin receptor function as well. To understand these changes, we will briefly review what is known about the transport of insulin through the blood-brain barrier.

The mechanisms by which insulin gains access to the CNS have recently been reviewed (Banks 2004). Although insulin and its receptors are widely spread throughout the brain (Dore et al., 1997. Schulingkamp et al., 2000. Zhao et al., 1999), apparently no significant insulin synthesis occurs in the CNS (Woodset et al., 2003). However, this conclusion has to be tempered by the presence of insulin mRNA in the brain and the possibility of restricted insulin synthesis in the brain (Devaskar et al., 1994). Most insulin is now thought to enter the brain through a receptor-based, saturable transporter that is largely saturated by serum levels of insulin that do not induce hypoglycemia (Banks et al., 1997a-c). Transport of insulin in the brain is highest in the olfactory bulb ( 8 times that found in the brain as a whole) followed by the pons, medulla, and hypothalamus (Banks et al., 1999). This level is consistent with the observation that the olfactory bulb has the highest concentration of insulin (Baskin et al., 1987). 
Evidence also suggests that insulin is released in the hypothalamic extracellular space in anticipation of a scheduled meal in rats. Such insulin release is independent of blood insulin levels, showing that certain brain regions can release insulin in relation to a learned association (Orosco et al., 1995). Additionally, a microdialysis study showed that intra-hypothalamic infusion of glucose increases extracellular insulin and that aging and obesity significantly reduce the glucosemediated insulin release (Gerozissis et al., 2001).

Thus, elevations in blood insulin levels will likely have different effects on different brain regions at different concentrations, owing to the disparity in insulin uptake into the brain. It is likely that in brain areas where insulin uptake is greatest, insulin could have regulatory effects whereas in areas where uptake is smaller and saturates at lower concentrations, insulin may have other effects, perhaps linked to a neurotrophic action.

Therefore, any theories involving brain insulin resistance will have to take into account not only the regional variations in transport mechanisms but also the concentrations of insulin and insulin receptors in the brain. As a result, insulin resistance in the brain could be due to changes in the receptor-based insulin carrier that would lead to reduced access of insulin to the brain or could be due to changes in insulin receptor function within the brain. One also has to take into account the large variations in blood insulin levels that follow ingestion of food and the feedback-related inhibition of insulin transport during hyperglycemia. We now turn to the effect of diabetes and aging on insulin transport and receptor function.

Hyperglycemia (in normal animals), obesity, and obesity-induced diabetes (in Zucker rats) decrease insulin transport into the brain (Banks et al., 1997a-b. Baskin et al., 1985. Kaiyala et al., 2000). Consistent with decreased insulin transport, obese Zucker rats have reduced brain levels of insulin (Baskin et al., 1985). However, in streptozotocin- or alloxan-induced diabetes, an increase in insulin transport to the brain occurs that is associated with the very low systemic insulin levels in these models. Such low levels of insulin result from the destruction of pancreatic beta cells. In animals, insulin receptors are highly expressed during development but decline during aging (Zhao et al., 1999). One human post-mortem study found that brain insulin, c-peptide, and insulin receptors are reduced in older individuals (Frolich et al., 1998).

Few studies have directly addressed the hypothesis of brain insulin resistance. In a model of metabolic syndrome (fructose-fed hamsters), which leads to obesity and impaired glucose tolerance, a downregulation of neural insulin signaling was noted, as measured by the stimulated tyrosine phosphorylation of the insulin receptor. The downregulation was accompanied by a reduced insulin-mediated long-term depression (LTD), although no change occurred in the presynaptically-mediated paired-pulse facilitation or in the expression of LTP, indicating normal hippocampal electrical activity. Thus, the establishment of neural insulin resistance leads to a reduction of insulin-induced changes in neural activity (Mielke et al., 2005). Other reports that identified the presence of insulin receptors in post-synaptic densities (Abbott et al., 1999) and showed that insulin can rapidly recruit $\mathrm{GABA}_{\mathrm{A}}$ receptors from the intracellular pool to the post-synaptic domain, suggesting a role for insulin in neural plasticity (Wan et al., 1997). Similarly, insulin has been shown to facilitate clathrin-mediated internalization of AMPA receptors, causing a form of long-term depression (Ahmadian et al., 2004). Also, insulin inhibits hippocampal pyramidal neurons in isolated brain slices at doses consistent with the presence of high affinity binding sites for insulin in the hippocampus (Palovick et al., 1984).

A recent study examined the effect of water maze training on the state of insulin receptors in 
the hippocampus of rats (Zhao et al., 1999). The authors found (a) an upregulation of insulin receptor mRNA in the CAl and dentate gyrus of the hippocampus, (b) an increased accumulation of insulin receptor protein in the hippocampal crude synaptic membrane fraction, and (c) a decrease in the cytosolic fraction. This result suggests that insulin receptors may be recruited to the synaptic membrane following neuronal activation. In the CA1 pyramidal neurons, changes in the distribution pattern of IR in particular cellular compartments, such as the nucleus and dendritic regions, were observed only in trained animals.

Mice with conditional inactivation of the insulin receptor gene (brain/neuron specific knockout) have a complete loss of insulin-mediated inhibition of neuronal apoptosis (and also a partial inhibition of the IGF-I induced inhibition of apoptosis, suggesting that the anti-apoptosis effect of IGF-I may be partly mediated by insulin receptor activation). However, these knockout mice showed no deficiencies in learning and memory and no difference in cerebral metabolism as measured by $18 \mathrm{~F}-\mathrm{FDG}$ micro-PET. Although Tau phosphorylation was increased, the increase was not accompanied by increased neurofibrillary tangles up to 18 months of age (Schubert et al., 2004).

In summary, brain insulin, most of which comes from the pancreas, is taken up by the brain by what appears to be a receptor-based carrier. Moreover, insulin is transported at various rates through the blood-brain barrier to different brain regions. Type 2 diabetes animal models, which are associated with insulin resistance, show a reduced uptake of insulin to the brain. Recent data point to changes in the insulin receptor cascade in obesityrelated insulin resistance, suggesting that brain insulin receptors also undergo changes similar to those observed in the periphery. Finally, insulin appears to modulate the membrane inclusion of GABA and AMPA receptors, suggesting a role in synaptic plasticity. The absence of insulin receptors in the brain of conditional knockout mice does not lead to any major deficit in learning and memory This observation suggests that insulin and insulin receptors have modulatory roles and their absence can be compensated by other mechanisms. We now turn to the various studies that have tried to link insulin to memory and cognitive functions in animals and humans.

\section{Diabetes, aging, and the brain}

A number of recent reviews have examined the impact of diabetes on brain functions and the possible link between diabetes and dementia (Awad et al., 2002. Messier, 2003. Messier et al., 2004. Strachan et al., 1997). The conclusions were that (a) type 2 diabetes is associated with an increased incidence of cognitive decline, particularly in patients older than 70 years, and (b) that diabetes appears to be a significant risk factor for vascular dementia and Alzheimer's disease. Several studies have also linked diabetes with brain atrophy. A Japanese MRI study found that brain atrophy was $40 \%$ more frequent in diabetic patients than in control participants, even though no difference in vascular pathology occurred, as revealed by the MRI (Araki et al., 1994). Similar findings were obtained in a study in the Netherlands showing that the volumes of the amygdala and hippocampus, two important structures for memory processing, were reduced in diabetic patients, regardless of vascular pathology (den Heijer et al., 2003). A smaller study also found a relation between an indirect measure of temporal lobe volume and fasting blood glucose in diabetic patients with a smaller temporal volume associated with drug-treated diabetic patients compared with diet-treated ones (Soininen et al., 1992). Finally, in normal aged humans, memory and hippocampal volume were found to be correlated to measures of glucose tolerance (Convit et al., 2003). Taken together, these studies suggest that the brain may be affected by changes in insulin levels in the 
periphery, and a number of recent studies have addressed the role of insulin on cognitive functions.

Another way to determine whether type 2 diabetes is associated with cognitive deficits is to evaluate the long-term effects of diabetes on cognitive function and whether changes over time are observable in repeated-measures designs. Longitudinal studies allow for such an assessment and limit the between-subjects variability observed in cross-sectional studies.

Two recent longitudinal studies have been conducted to evaluate the relation between cognitive decline and type 2 diabetes. Gregg et al. (2000) compared the performance of 682 diabetic women (mean duration of type 2 diabetes $=10.2$ years. SD $=9.5$ years) to the performance of 8997 agematched women (mean age $=72$ years) who were assessed on two occasions: at baseline and 3 to 6 years following baseline assessment. Variables such as age, education, depression, hypertension, and cardiovascular disease were methodologically controlled. The neuropsychological assessment included a modified version of the Mini-Mental State Examination as a brief cognitive screening measure, a psychomotor speed test, and a measure of frontal lobe/executive function. The results of this study revealed an increased odds of major cognitive decline in type 2 diabetic patients (defined as the greatest $10^{\text {th }}$ percentile reduction in performance from initial to follow-up score) on the psychomotor speed test and the measure of frontal lobe/executive function-Digit Symbol test (Wechsler 1981) and Trails B test (Spreen \& Strauss 1998).

A second longitudinal study compared the performance of 55 type 2 diabetes participants with the performance of 103 participants with impaired fasting glucose and 768 age-matched controls (mean age $=65$ years) on several neuropsychological tests. These tests included the MiniMental State Examination, as well as measures of verbal and visual memory, facial recognition, executive function, motor function, arithmetic ability, processing speed, and logical reasoning (Fontbonne et al., 2001). The authors controlled for age, gender, education, depression, hypertension, and body mass index. They reported, however, that diabetic participants had higher levels of triglycerides, as well as lower levels of total cholesterol and HDL cholesterol compared with controls. The authors concluded that the odds ratios for 'serious worsening' were greater than 2 for measures of verbal memory, facial recognition, processing speed, and motor function. Serious worsening is defined as a change in memory scores down to the lowest $15 \%$ of the distribution of the observed changes for the whole sample. Taken together, these longitudinal studies suggest that participants with type 2 diabetes are at higher risk for cognitive decline compared with agematched controls.

The findings of these longitudinal studies are further substantiated by studies evaluating risk of co-existence of diabetes and dementia (reviewed in Messier, 2003). Some studies evaluating the coexistence of these two diseases demonstrated a moderate association between diabetes and Alzheimer's disease, with odds ratios ranging from 1.3 to 1.9 (Brayne et al., 1998. Ott et al., 1996. Ott et al., 1999. Peila et al., 2002). This finding has not been consistently observed, however, as other studies have not reported such associations (Odds ratios ranging from 1.0 to 1.3. (Curb et al., 1999. Leibson et al., 1997. Luchsinger et al., 2001). Recently, Peila et al. (2002) demonstrated that the odds ratio for the co-existence of diabetes and Alzheimer's disease significantly increased only for subjects with the ApoE4 allele. Post-mortem examination of these subjects revealed that Alzheimer's patients who were diabetic had an increased number of infarcts and that the ApoE4 allele was associated with increased neurofibrillary tangles in the hippocampus and cortex, as well as increased cerebral amyloid angiopathy. Although several reports found that Alzheimer's 
disease was associated with hyperinsulinemia (Bucht et al., 1983. Craft et al., 1993. Craft et al., 1996. 1998), others did not (Fujisawa et al., 1991. Kilander et al., 1993). Two studies found that compared with ApoE2 bearers, bearers of the ApoE4 allele tend to have lower insulin levels (Craft et al., 1998. Gonzalez et al., 1999).

The relation between diabetes and Alzheimer's disease remains unclear, but could be mediated by the insulin-degrading enzyme (IDE), which also degrades beta-amyloid protein. Given that insulin competes with beta-amyloid for the insulindegrading enzyme, it has been proposed that in certain cases, Alzheimer's disease amyloid deposition can be increased by excessive levels of insulin (Cook et al., 2003. Craft et al., 2000. Ling et al., 2002). However, there is no indication that high levels of insulin or diabetes, as such, independently produce amyloid deposition of neurofibrillary tangles (Heitner \& Dickson 1997. Peila et al., 2002), suggesting that diabetes is not a cause of Alzheimer's pathology. Rather, insulin may further aggravate the pathologies already present in Alzheimer's patients. This possibility will be discussed further below.

In the preceding sections, we have examined the possibility that the insulin resistance found in muscle and fat tissues in people with peripheral insulin resistance and type 2 diabetes may also be found for insulin receptors in the brain. Together, the observations that suggest that insulin transport to the brain is reduced in aging, and in some animal models of type 2 diabetes, has led to the proposal that stimulation of the brain's insulin receptors could facilitate brain function and, more precisely, learning and memory. This hypothesis has been tested using several methodologies, as described in the next section.

\section{Effect of insulin on cognitive functions}

Very few studies have shown a beneficial effect of peripheral insulin injections on brain functions owing to the hypoglycemic action of insulin and the deleterious effect of hypoglycemia on brain function (Kopf \& Baratti 1995, 1999). One experiment, however, showed that insulin injected in conjunction with glucose improved memory in rats (Messier \& White 1987). Similarly, the peripheral injection of small doses of insulin reversed the amnesia produced by scopolamine in a food-motivated operant task (Blanchard \& Duncan 1997. Messier \& Destrade 1994). Intracerebroventricular injection of insulin was shown to improve the performance on an avoidance task (Park et al., 1995), although no effect on memory was found following intrahippocampal insulin injection in rats (Paulus et al., 2005).

The observations that insulin, insulin receptors, and C-peptide levels in cerebral spinal fluid (CSF) appear to be reduced in aging, (Frolich et al., 1998) along with the finding that Alzheimer's patients have lower levels of insulin in the CSF (Craft et al., 1998) suggest impaired transport of insulin into the CSF. The results of these studies have prompted several studies examining the effect of insulin in young and old persons.

The effect of insulin on brain function in humans has been studied using two experimental protocols. In the first, the hyperinsulinemic clamp procedure, increased blood insulin levels are maintained while glucose is infused intravenously to keep blood glucose levels close to normal fasting levels. One study showed that verbal memory is improved in Alzheimer's patients but not in normal age-matched controls during the hyperinsulinemic clamp procedure (Craft et al., 1996).

A second study that also used the hyperinsulinemic clamp showed that insulin improves the memory of younger patients for emotional words, and also produces changes in the evoked potentials P300 latencies, suggesting an influence of insulin on attentional-cognitive functions (Kern et al., 2001). Another study examined the impact of different blood insulin levels using the hyperinsulinemic clamp in Alzheimer patients and 
aged-matched controls. Patients homozygotic for the APOE4 genotype and healthy controls had better recall at the low insulin levels $(150 \mathrm{pmol} / \mathrm{L})$, whereas patients with no APOE4 alleles had better recall at higher insulin levels $(219 \mathrm{pmol} / \mathrm{L})$ (Craft et al., 2003), suggesting a dose-response curve specific for each population.

In an FDG-PET study using the euglycemic clamp, the effect of insulin together with a glucose infusion produced an increase in cerebral glucose uptake (Bingham et al., 2002). In this study, somatostatin was given to suppress endogenous insulin secretion, and intravenous glucose was used to keep blood glucose levels at $5 \mathrm{mmol} / \mathrm{L}$. Little glucose was infused in the control condition, but an average of $292.45 \mathrm{mg} / \mathrm{kg}$ of glucose was infused to keep glucose levels stable during the insulin infusion. As a result, the study actually demonstrated the combined effect of exogenous insulin and glucose on cerebral glucose uptake. This effect may be exerted either through a metabolic effect of insulin on brain glucose uptake or through a neuronal activation produced by the combined glucose-insulin infusion.

Another approach that has been taken to introduce insulin into the brain is intranasal administration. Experimental studies using mice (Gizurarson et al., 1995), rats (Thorne, et al., 2004) or monkeys (Anand et al., 1974. Gopinath et al., 1978) showed that peptides delivered into the nasal cavity via, or close to, the olfactory epithelium are transported into the brain within 10 to 15 minutes. Various mechanisms are thought to allow peptides to enter the brain through the intranasal route, although the precise mechanisms have not been elucidated. The mechanism most likely to provide rapid entry into the brain involves an extraneuronal pathway through perineural channels that deliver peptides to the parenchyma and/or the CSF (Frey, 2002).

Another possible route is along the trigeminal neural pathway (Thorne et al., 2004). A detailed analysis of the transfer of IGF-I from the nose to the brain showed significant IGF-I concentrations in most brain regions after $30 \mathrm{~min}$, with olfactory structures having the highest concentration (Thorne et al., 2004). Detectable IGF-I concentrations were found in the hippocampus, midbrain, cerebellum, medulla, and cervical spinal cord, showing a wide distribution in the brain $30 \mathrm{~min}$ after intranasal administration. A double-blind crossover study looking at the safety of intranasal insulin revealed no adverse effects after three weeks of daily 60IU intranasal insulin administration (Kupila et al., 2003). More-over, no effect on blood glucose levels was found, indicating that intranasal insulin does not induce hypoglycemia.

A study examined the effect of $201 \mathrm{IU}$ of insulin administered in the nasal cavities every $15 \mathrm{~min}$ for $2.5 \mathrm{~h}$ in adult male volunteers of normal weight (Kern et al., 1999). At 30 min and $2 \mathrm{~h}$, an EEG was recorded to assess auditory-evoked brain potentials. Baseline-to-peak amplitudes of the N1 (but not P2) component of auditory-evoked brain potentials were reduced during insulin infusions for the central $(\mathrm{Cz})$ and parietal $(\mathrm{Pz})$ locations. The amplitude of the P3 component was also reduced during insulin infusion at the frontal, parietal, and central location with the frontal location showing the greatest amplitude changes, whereas the central and parietal locations were reduced only within $500 \mathrm{~ms}$ of the stimulus presentation. The results of these studies are similar to those obtained previously by the same groups using the hyperinsulinemic/euglycemic clamp, for which insulin levels are kept elevated while glucose levels are kept at fasting levels through intravenous glucose infusion (Kern et al., 1998) or during insulin-induced hypoglycemia (Kern et al., 1990. Tamburrano et al., 1988).

The results of these studies suggest that insulin itself is the cause of the observed neuroelectric changes. Another study used the hyperinsulinemic/ euglycemic clamp to study the effect of low and high levels of blood insulin on evoked brain potentials, as well as on neuropsychological performance (Kern et al., 2001). The results 
revealed no difference between the $\mathrm{N} 1$ and $\mathrm{P} 2$ components elicited during the presentation of frequent tones under low and high insulin levels. An increase in P3 latency at the frontal and parietal placement was observed but, contrary to the intranasal study, no clear baseline-to-peak P3 amplitude increase. There was an increase in slow wave in the frontal regions during the high insulin condition and a small increase in the number of emotional and food-related words recalled toward the end of the $6 \mathrm{~h}$ of testing, which was concurrent with an increase of correct responses during the interference condition of the Stroop test and increases in the feeling of hunger.

Lastly, an experiment examined the effect of 8 weeks of intranasal insulin on cognitive performance and mood (Benedict et al., 2004). A $40 \mathrm{IU}$ insulin dose was infused into the nose 4 times a day. The participants were first tested during the placebo phase of the trial, after the infusion of the first insulin solution, and 1 week before the end of the trial. No difference was found between the per-formance of the insulin and saline groups for memory, except for delayed recall of words tested 1 week after the last testing session. Furthermore, no effect of insulin on the Stroop test or on word stem completion was found. There were, however, increases in the self-rating mood scores for self-confidence and well-being, as well as a reduced self-rating of depression after receiving insulin for 8 weeks (Benedict et al., 2004). Finally, one recent trial showed that intranasal insulin (20 IU) im-proved declarative memory in Alzheimer's patients and, to a lesser degree, in older adults (Baker et al., 2003).

In summary, studies that examined the effect of the hyperinsulinic clamp on cognitive function found a small but consistent improvement in memory and changes in brain neuroelectric parameters in evoked brain potentials, consistent with improved attention or memory processing. One PET study using the hyperinsulinemic/euglycemic clamp showed that brain glucose uptake increased during that procedure, suggesting that this increase may underlie the effect of the clamp procedure on brain functions. Studies using intra-nasal insulin reported cognitive improvements similar to those described with the hyperinsulin-emic clamp, suggesting that the effects of this procedure are likely due to increased brain insulin levels.

The final sections of this review deals with the possible interaction between the brain's insulin and IGF-I signaling pathways, as well as their possible role in brain aging and Alzheimer's disease. The literature on insulin growth factors and their roles in development and brain maturing is extensive and will not be reviewed here except for a brief presentation of key facts. The reader is referred to the comprehensive review by Juul (2003) for an exhaustive overview of IGF-I roles, physiology, and biochemistry.

\section{INSULIN AND INSULIN GROWTH FACTOR-1}

Insulin, insulin growth factor 1 (IGF-I) and insulin growth factor 2 (IGF-II) are ubiquitous molecules that have important roles in maintaining homeostasis, in postnatal growth, and in development (Juul, 2003). Insulin, IGF-I, and IGF-II each has its own receptor but cross-interact with low affinity with each others' receptors. In blood, insulin is found in picomolar concentrations whereas IGF-I is found in nanomolar concentrations. In theory, this would lead to a much higher impact of IGF-I on all three receptors if not for the finding that much of the IGF is bound to IGF binding proteins (IGFBP-3) in the blood, which blocks its biological activity (Baxter et al., 1998). Both IGF-I and IGFBP-3 decrease monotonically after puberty (Juul et al., 1994).

Insulin and IGF-I are genetically related polypeptides that share substantial amino acid sequences. Although insulin is synthesized in the pancreas, IGF-I is produced by the liver, and its expression is enhanced by pituitary growth 
hormone. IGF-I is also synthesized in the brain, where growth hormone does not influence its expression (Bondy \& Cheng 2004). In rats, the expression of mRNA for IGF-I is maximal during development of the nervous system but remains expressed in the adult brain in many regions including the hippocampus, olfactory bulb, hypothalamic area, and cerebellum, as well as in epithelial and ependymal cells of the choroids plexus (Rotwein et al., 1990).

Overexpression of IGF-I in transgenic animals results in increased brain size and myelination (Carson et al., 1993), whereas IGF-I knockout animals have smaller brains, a smaller granule cell layer in the dentate gyrus, and lower numbers of oligodendrocytes and myelinated axons (Beck et al., 2004). The role of IGF-I is also illustrated by a recent report showing that when weaver mutant mice, who exhibit apoptosis of cerebellar granule neurons, are cross-bred with transgenic mice overexpressing IGF-I, an increase in surviving granule cells and a decrease in apoptotic cells reduced the impact of the weaver mutation (Zhong et al., 2005). IGF-I transgenic animals were also shown to have greater number of synapses during and after post-natal development (O'Kusky et al., 2000. 2003).

Another series of experiments ex-amined the effect of IGF-I on cell differentiation in multipotent adult neural progenitor cells and found that IGF-I played an instructive role by shifting the differentiation process from the production of astrocytes to oligodendrocytes and, to a lesser extent, neurons (Hsieh et al., 2004). This effect was thought to be dependent on the indirect inhibition of the bone morphogenetic protein (BMP) signaling by the upregulation of BMP antagonists Noggin, Smad6, and Smad7.

Although much remains to be done in elucidating the role of IGF-I using transgenic animals, the general view is that IGF-I controls and/or enables the growth of new brain cells including neurons and glia, reduces developmental apoptosis, and increases synaptogenesis during early post-natal development (D'Ercole et al., 2002).

A number of observations have led researchers to study the role of IGF-I in aging and dementia. In a small study, it was found that IGF-I blood levels are correlated with MMSE performance in older persons (65 years and over), with lower levels of IGF-I being associated with lower performance in the MMSE (Rollero et al., 1998). Plasma insulinlike growth factor I (IGF-I) level was reduced in family members carrying the Swedish amyloid precursor protein (APP) 670/671 mutation with Alzheimer's disease (AD) compared with agematched controls from the same family carrier without AD (Mustafa et al., 1999).

Also, IDDM and severe insulin resistance may cause acquired IGF-I resistance through a decrease in IGF-I availability or altered second messenger systems (Jain et al., 1998). Studies in patients with diabetes have shown that in insulin-deficient states, serum IGF-I concentrations are low and increase with insulin therapy (Bereket et al., 1996). Although total IGF-I has been found to be within normal values in type 2 diabetes, free IGF-I remains elevated in type 2 diabetic patients to a degree similar to that observed in obese individuals without diabetes (Frystyk et al., 1999). In normal subjects, low IGF-I is associated with high 2-h glucose concentrations during a glucose tolerance test (Sandhu et al., 2002), indicating that IGF-I has a role in peripheral uptake of glucose.

Studies conducted in experimental animals have shown that if IGF-I synthesis by the liver is stopped, the animals become insulin-resistant, and this situation is improved when IGF-I is administered. Likewise, deletion of the IGF-I receptor in muscle tissue in mice induces severe insulin resistance. The administration of IGF-I to patients with type 2 diabetes mellitus has been shown to result in an improvement in insulin sensitivity and a reduction in the requirement for exogenously administered insulin to maintain glucose homeostasis (Clemmons, 2004). 
In summary, IGF-I is involved in brain development and maturation. Peripheral levels are associated with peripheral glucose regulation and interact with insulin mechanisms that control glucose disposal. In the next section, we briefly review the results of studies that have examined the impact of insulin and IGF-I on amyloid production and disposal in animal models and in patients with Alzheimer's disease.

\section{INSULIN AND IGF-I AND AMYLOID ACCUMULATION}

Beta-amyloid (A $\beta$ ) is a potentially deleterious compound when it accumulates in the aging brain and is associated with Alzheimer's disease (Selkoe, 2001). During aging, IGF-I levels decline, with a decreased sensitivity to insulin and IGF-I as well (Jain et al., 1998). Both hormones are presumed to help reduce beta-amyloid toxicity by increasing its cellular release (Gasparini et al., 2001), stimulating tissue clearance (Carro et al., 2002), and protecting from its toxic effects (Niikura et al., 2001).

Previous experiments had shown an increased uptake of insulin at the blood brain barrier of the Tg2576 (double transgenic APP and PS1) mouse (Poduslo et al., 2001) and when fed a highcholesterol diet for 7 weeks, an increased amyloid load and deposit size in the $\mathrm{Tg} 2576$ mouse (Refolo et al., 2000). In a more recent experiment, $\mathrm{Tg} 2576$ mice were given access to a $60 \%$ fat diet and it was found that the diet induced insulin resistance, higher weight, and higher evoked blood glucose levels, but no change in total cholesterol occurred compared with standard-chow-fed animals (Ho et al., 2004).

However, a 5-month exposure to the diet doubled the amount of $A \beta-40$ and $A \beta 42$ and also increased the number and volume of $6 \mathrm{E} 10$ immunopositive amyloid plaques. The high-fat diet also reduced markers of insulin receptor activity (PI3K, AKT/PKB, and Glycogen synthase kinase-
$3 \alpha$ [GSK-3 $\alpha]$ ), consistent with insulin resistance and reduced performance in the water maze. Finally, the high-fat diet also reduced IDE expression and activity.

On the other hand, the inhibition of GSK-3 $\alpha$ by lithium chloride has heen shown to decrease the production of amyloid peptides in animal models of Alzheimer's disease (Phiel et al., 2003), which would suggest that higher insulin receptor activity leads to higher amyloid production. In cell cultures, it was shown that insulin decreases intracellular levels of $A \beta 40$ and $A \beta 42$, which appeared to be mediated by an accelerated transfer from the Golgi/transGolgi net-work to the plasma membrane (Gasparini et al., 2001).

There is now good evidence that insulindegrading enzyme (IDE) is one of the proteins that degrades beta-amyloid in vivo and in vitro and is selective for the AB monomer (Farris et al., 2003. Vekrellis et al., 2000). Additionally, a number of linkage studies have identified chromosome $10 \mathrm{q}$ as a site of a number of markers for increased plasma levels of beta amyloid that are close to the IDE site (Bertram et al., 2000. Ertekin-Taner et al., 2000, 2004. Prince et al., 2003), although a number of genetic studies concluded that IDE was not associated with late-onset Alzheimer's disease (Abraham et al., 2001. Boussaha et al., 2002).

Two recent studies suggested that IDE variant expres-sion may affect Alzheimer's severity rather than risk (Blomqvist et al., 2005), and there may be inefficient forms of IDE that foster poor amyloid processing (Farris et al., 2005). Some post-mortem studies have also indicated that hippocampal IDE levels and mRNA were decreased in $A D$ brain tissue from patients with the APOE4 gene (Cook et al., 2003).

Using the Brain Efflux Index, a study showed that $A \beta(1-40)$ elimination from the brain was reduced by $30 \%$ in old rats, whereas inhibitors of neprilysin and IDE (the two main amyloiddegrading enzymes) reduced $A \beta$ efflux by $25 \%$ to $30 \%$ (Shiiki et al., 2004). Neprilysin knockout 
mice have a two-fold increase in $A \beta \quad(1-40)$ and $A \beta(1-42)$ in the brain (Iwata et al., 2000), but a $34 \%$ inhibition of $\mathrm{A} \beta$-elimination rate by thiorphan, a neprilysin inhibitor, suggests that neprilysin action is non-saturable or that $A \beta$ fragments inhibit their efflux transport (Shiiki et al., 2004). In the same study, the co-administration of insulin with $A \beta(1-40)$ reduced the elimination rate of $A \beta(1-40)$ and increased the level of intact $A \beta(1-40)$ in the brain (Shiiki et al., 2004). The results of that study parallel those obtained in humans, in which systemic insulin infusions led to an increase in CSF A $\beta$ (1-42) (Watson et al., 2003). One possibility is that insulin competes with $A \beta(1-40)$ (Xie et al., 2002) for transcytosis transport using the insulin receptor at the BBB (Pardridge et al., 1995). However, an inhibitor of the insulin receptor kinase failed to affect $A \beta$ elimination rate (Shiiki et al., 2004).

Another experiment using hippocampal cell cultures showed that treatment with insulin produced an increase in IDE-protein levels, which was accompanied by an increase in phosphadylinositol-3 (PI-3) (Zhao et al., 2004). The inhibition of PI-3 abolished the upregulation of IDE by insulin, suggesting that the effect of insulin on IDE may be mediated through an activation of the insulin receptor. The authors also showed that in $\mathrm{Tg} 2576$ mice raised on a safflower oil-based diet, a reduction in IDE mRNA and protein expression correlated with the level of beta-amyloid in the hippocampus.

Finally, a post-mortem study showed reduced IDE levels in the hippocampus and temporal cortex of Alzheimer's patients, and the highest reductions were found in patients with two copies of the ApoE4 allele (Zhao et al., 2004). Additionally, levels of IDE and neprilysin were found to be lower in the human hippocampus and cortex compared with levels in the cerebellum, a structure having fewer amyloid deposits in $\mathrm{AD}$ (Caccamo et al., 2005). The same study also found that $75 \%$ of IDE was oxidized in the AD hippo- campus compared with $25 \%$ in the cerebellum, suggesting the possibility that the enzymatic activity of oxidized IDE may be reduced, leading to increased amyloid deposition (Caccamo et al., 2005). This result is consistent with the observation that in transgenic mice overexpressing APP, A $\beta$ amyloid deposition increases in a progressive, agerelated fashion, despite the presence of high APP levels throughout their lifetime. Taken together, the results of these studies support the hypothesis that amyloid accumulation in the aging brain is due to deficits in degradation rather than to an increase in amyloid production, and that brain insulin, insulin receptor activity, or the insulin degrading enzyme play a role in the clearance of $A \beta$ amyloid.

\section{GENERAL CONCLUSIONS}

Brain insulin, most of which comes from the pancreas, is taken up by the brain by what appears to be a receptor-based carrier. Insulin is transported at various rates through the blood-brain barrier to different brain regions.

Type 2 diabetes animal models associated with insulin resistance show reduced insulin brain uptake and content. Some recent data point to changes in the insulin receptor cascade in obesity-related insulin resistance, which is consistent with a reduced sensitivity of insulin receptors. Such changes are accompanied by reductions in synaptic plasticity. The absence of insulin receptors in the brain of conditional knockout mice does not reveal any major deficit in learning and memory, suggesting that insulin and insulin receptors have modulatory roles, or that compensatory mechanisms exist.

Insulin transport to the brain is reduced in aging and in some animal models of type 2 diabetes. Because brain- insulin uptake is receptor based, insulin resistance would thus lead to a reduction in both insulin uptake and the ability of 
insulin to stimulate its receptors in the brain.

Studies examining the effect of the hyperinsulinic clamp or intranasal insulin on cognitive function have found a small but consistent improvement in memory and changes in brain neuroelectric parameters in evoked brain potentials. These changes are consistent with improved attention or memory processing. These effects appear to be due to raised brain insulin levels. The results also suggest that a reduction in brain insulin or brain insulin sensitivity could be the cause of some of the cognitive deficits observed in persons with impaired glucose tolerance or type 2 diabetes.

Insulin growth factor-I is involved in brain development and maturation. Peripheral levels are associated with peripheral glucose regulation and interact with insulin mechanisms that control glucose disposal. There is some indication that decreased sensitivity to insulin or to IGF-I as observed in aging, obesity, and diabetes decreases the clearance of $A \beta$ amyloid through processes that appear to involve the insulin receptor. However, the exact sequence of cellular events for these processes remains to be elucidated. Insulin and IGF-I also appear to modulate the brain levels of insulin degrading enzyme. This enzyme has been shown to be important in the degradation of insulin and a reduction of its activity would lead to accumulation of $A \beta$ amyloid. This hypothesis is consistent with the observation that amyloid deposition is increased both in transgenic animal models of Alzheimer's disease that are diabetic and in diabetic patients suffering from Alzheimer's disease.

\section{AKNOWLEDGMENTS}

This research was supported by a grant from the Natural Sciences and Engineering Council of Canada to C.M. We would like to thank Lyssa Gagnon and Valérie Mertens for their help in revising this manuscript.

\section{REFERENCES}

Abbott MA, Wells DG, Fallon JR. 1999. The insulin receptor tyrosine kinase substrate p58/53 and the insulin receptor are components of CNS synapses. J Neurosci 19: 7300-7308.

Abraham R, Myers A, Wavrant-DeVrieze F, Hamshere ML, Thomas HV, Marshall H, et al. 2001. Substantial linkage disequilibrium across the insulin-degrading enzyme locus but no association with late-onset Alzheimer's disease. Hum Genet 109: 646-652.

Ahmadian G, Ju W, Liu L, Wyszynski M, Lee SH, Dunah AW, et al. 2004. Tyrosine phosphorylation of GluR2 is required for insulin-stimulated AMPA receptor endocytosis and LTD. Embo J 23: 10401050.

Anand Kumar TC, David GFX, Umberkoman B, Saini KD. 1974. Uptake of radioactivity by body fluids and tissues in rhesus monkeys after intravenous injection or intranasal spray of tritiumlabelled estradiol and progesterone. Curr Sci 1974. 43: 435-439.

Araki Y, Nomura M, Tanaka H, Yamamoto H, Yamamoto T, Tsukaguchi I, et al. 1994. MRI of the brain in diabetes mellitus. Neuroradiology 36: 101-103.

Awad N, Gagnon M, Messier C. 2004. The relationship between impaired glucose tolerance, type 2 diabetes, and cognitive function. J Clin Exp Neuropsychol 26: 1044-1080.

Baker LD, Watson GS, Cholerton B, Reger MA, Chapman D, Hyde K, et al. 2003. Acute Intranasal Insulin Administration Improves Verbal Memory for Adults With Alzheimer's Disease. Society for Neuroscience Meeting.

Banks WA. 2004. The source of cerebral insulin. Eur J Pharmacol 490: 5-12.

Banks WA, Jaspan JB, Huang W, Kastin AJ. 1977a. Transport of insulin across the blood-brain barrier: saturability at euglycemic doses of insulin. Peptides 18: 1423-1429.

Banks WA, Jaspan JB, Kastin AJ. 1997b. Effect of diabetes mellitus on the permeability of the bloodbrain barrier to insulin. Peptides 18: 1577-1584.

Banks WA, Jaspan JB, Kastin AJ. 1997c. Selective physiological transport of insulin across the blood-brain barrier: novel demonstration by species-specific radioimmunoassays. Peptides 18: 1257-62.

Banks WA, Kastin AJ, Pan W. 1999. Uptake and 
degradation of blood-borne insulin by the olfactory bulb. Peptides 20: 373-8.

Baskin DG, Figlewicz DP, Woods SC, Porte D Jr, Dorsa DM. 1987. Insulin in the brain. Annu Rev Physiol 49: 335-347.

Baskin DG, Stein LJ, Ikeda H, Woods SC, Figlewicz DP, Porte D Jr, et al. 1985. Genetically obese Zucker rats have abnormally low brain insulin content. Life Sci 36: 627-633.

Baxter RC, Binoux MA, Clemmons DR, Conover CA, Drop SL, Holly JM, et al. 1998. Recommendations for nomenclature of the insulin-like growth factor binding protein superfamily. J Clin Endocrinol Metab 83: 3213. also Endocrinology 139: 4036.

Beck KD, Powell-Braxton L, Widmer HR, Valverde J, Hefti F. 1995. Igfl gene disruption results in reduced brain size, CNS hypomyelination, and loss of hippocampal granule and striatal parvalbumin-containing neurons. Neuron 14: 717-730.

Benedict C, Hallschmid M, Hatke A, Schultes B, Fehm $\mathrm{HL}$, Born J, et al. 2004. Intranasal insulin improves memory in humans. Psychoneuroendocrinology 29: 1326-1334.

Bereket A, Lang CH, Blethen SL, Ng LC, Wilson TA. 1996. Insulin treatment normalizes reduced free insulin-like growth factor-I concentrations in diabetic children. Clin Endocrinol (Oxf) 45: 321-326.

Bertram L, Blacker D, Mullin K, Keeney D, Jones J, Basu S, et al. 2000. Evidence for genetic linkage of Alzheimer's disease to chromosome 10q. Science 290(5500): 2302-2303.

Biessels GJ, van der Heide LP, Kamal A, Bleys RL, Gispen WH. 2002. Ageing and diabetes: implications for brain function. Eur J Pharmacol 441: 1-14.

Bingham EM, Hopkins D, Smith D, Pernet A, Hallett W, Reed L, et al. 2002. The role of insulin in human brain glucose metabolism: an 18fluorodeoxyglucose positron emission tomography study. Diabetes 51: 3384-3390.

Blanchard JG, Duncan, PM. 1997. Effect of combinations of insulin, glucose and scopolamine on radial arm maze performance. Pharmacol Biochem Behav 58: 209-214.

Blomqvist ME, Chalmers K, Andreasen N, Bogdanovic N, Wilcock GK, Cairns NJ, et al. 2005. Sequence variants of IDE are associated with the extent of beta-amyloid deposition in the Alzheimer's disease brain. Neurobiol Aging 26: 795-802.

Bondy CA, Cheng, CM. 2004. Signaling by insulin- like growth factor 1 in brain. Eur J Pharmacol 490: 25-31.

Boussaha M, Hannequin D, Verpillat P, Brice A, Frebourg T, Campion D. 2002. Polymorphisms of insulin degrading enzyme gene are not associated with Alzheimer's disease. Neurosci Lett 329: 121123.

Brayne C, Gill C, Huppert FA, Barkley C, Gehlhaar E, Girling DM, et al. 1998. Vascular risks and incident dementia: results from a cohort study of the very old. Dement Geriatr Cogn Disord 9: 175-180.

Bruning JC, Gautam D, Burks DJ, Gillette J, Schubert M, Orban PC, et al. 2000. Role of brain insulin receptor in control of body weight and reproduction. Science 289(5487): 2122-2125.

Bucht G, Adolfsson R, Lithner F, Winblad B. 1983. Changes in blood glucose and insulin secretion in patients with senile dementia of Alzheimer type. Acta Med Scand 213: 387-392.

Caccamo A, Oddo S, Sugarman MC, Akbari Y, La Ferla FM. 2005. Age- and region-dependent alterations in Abeta-degrading enzymes: implications for Abeta-induced disorders Neurobiol Aging 26: 645-654.

Carro E, Trejo JL, Gomez-Isla T, LeRoith D, TorresAleman I. 2002. Serum insulin-like growth factor I regulates brain amyloid-beta levels. Nat Med 8: 1390-1397.

Carson MJ, Behringer RR, Brinster RL, McMorris FA. 1993. Insulin-like growth factor I increases brain growth and central nervous system myelination in transgenic mice. Neuron 10: 729-740.

Clemmons DR. 2004. Role of insulin-like growth factor in maintaining normal glucose homeostasis. Horm Res 62 Suppl 1: 77-82.

Convit A, Wolf OT, Tarshish C, de Leon MJ. 2003. Reduced glucose tolerance is associated with poor memory performance and hippocampal atrophy among normal elderly. Proc Natl Acad Sci USA. 100: 2019-2022.

Cook DG, Leverenz JB, McMillan PJ, Kulstad JJ, Ericksen S, Roth RA, et al. 2003 Reduced hippocampal insulin-degrading enzyme in late-onset Alzheimer's disease is associated with the apolipoprotein E-epsilon4 allele. Am J Pathol 162: 313-319.

Craft S, Asthana S, Cook DG, Baker LD, Cherrier M, Purganan $\mathrm{K}$, et al. 2003. Insulin dose-response effects on memory and plasma amyloid precursor 
protein in Alzheimer's disease: interactions with apolipoprotein E genotype. Psychoneuroendocrinology 28: 809-822.

Craft S, Asthana S, Schellenberg G, Baker L, Cherrier $\mathrm{M}$, Boyt AA, et al. 2000. Insulin effects on glucose metabolism, memory, and plasma amyloid precursor protein in Alzheimer's disease differ according to apolipoprotein-E genotype. Ann NY Acad Sci 903: 222-228.

Craft S, Dagogo-Jack SE, Wiethop BV, Murphy C, Nevins RT, Fleischman S, et al. 1993. Effects of hyperglycemia on memory and hormone levels in dementia of the Alzheimer type: a longitudinal study. Behav Neurosci 107: 926-940.

Craft S, Newcomer J, Kanne S, Dagogo-Jack S, Cryer P, Sheline Y, et al. 1996. Memory improvement following induced hyperinsulinemia in Alzheimer's Disease. Neurobiol Aging 17: 123130.

Craft S, Peskind E, Schwartz MW, Schellenberg GD, Raskind M, Porte D Jr. 1998. Cerebrospinal fluid and plasma insulin levels in Alzheimer's disease: relationship to severity of dementia and apolipoprotein E genotype. Neurology 50: 164-168.

Curb JD, Rodriguez BL, Abbott RD, Petrovitch H, Ross GW, Masaki KH, et al. 1999. Longitudinal association of vascular and Alzheimer's dementias, diabetes, and glucose tolerance. Neurology 52: 971-915.

D'Ercole AJ, Ye P, O'Kusky, JR. 2002. Mutant mouse models of insulin-like growth factor actions in the central nervous system. Neuropeptides 36: 209 220.

den Heijer T, Vermeer SE, van Dijk EJ, Prins ND, Koudstaal PJ, Hofman A, et al. 2003. Type 2 diabetes and atrophy of medial temporal lobe structures on brain MRI. Diabetologia 46: 16041610.

Devaskar SU, Giddings SJ, Rajakumar PA, Carnaghi LR, Menon RK, Zahm DS. 1994. Insulin gene expression and insulin synthesis in mammalian neuronal cells. J Biol Chem 269: 8445-8454.

Dore S, Kar S, Rowe W, Quirion R. 1997. Distribution and levels of [125I]IGF-I, [125I]IGF-II and [125I]insulin receptor binding sites in the hippocampus of aged memory-unimpaired and -impaired rats. Neuroscience 80: 1033-1040.

Ertekin-Taner N, Allen M, Fadale D, Scanlin L, Younkin L, Petersen RC, et al. 2004. Genetic variants in a haplotype block spanning IDE are significantly associated with plasma Abeta42 levels and risk for Alzheimer disease. Hum Mutat 23: 334-342.

Ertekin-Taner N, Graff-Radford N, Younkin LH, Eckman C, Baker M, Adamson J, et al., 2000. Linkage of plasma Abeta42 to a quantitative locus on chromosome 10 in late-onset Alzheimer's disease pedigrees. Science 290(5500): 2303-2304.

Farris W, Leissring MA, Hemming ML, Chang AY, Selkoe DJ. 2005 Alternative splicing of human insulin-degrading enzyme yields a novel isoform with a decreased ability to degrade insulin and amyloid beta-protein. Biochemistry 4417: 65136525.

Farris W, Mansourian S, Chang Y, Lindsley L, Eckman EA, Frosch MP, et al. 2003. Insulindegrading enzyme regulates the levels of insulin, amyloid beta-protein, and the beta-amyloid precursor protein intracellular domain in vivo. Proc Natl Acad Sci USA 100: 4162-4167.

Fontbonne A, Berr C, Ducimetiere P, Alperovitch A. 2001. Changes in cognitive abilities over a 4-year period are unfavorably affected in elderly diabetic subjects: results of the Epidemiology of Vascular Aging Study. Diabetes Care 24: 366-370.

Frey W. 2002. Intranasal delivery: bypassing the blood-brain barrier to deliver therapeutic agents to the brain and spinal cord. Drug Deliv Technol 2: 46-49.

Frolich L, Blum-Degen D, Bernstein HG, Engelsberger S, Humrich J, Laufer S, et al. 1998. Brain insulin and insulin receptors in aging and sporadic Alzheimer's disease. J Neural Transm 105: 423438.

Frystyk J, Skjaerbaek C, Vestbo E, Fisker S, Orskov H. 1999. Circulating levels of free insulin-like growth factors in obese subjects: the impact of type 2 diabetes. Diabetes Metab Res Rev 15: 314-322.

Fujisawa Y, Sasaki K, Akiyama K._1991 Increased insulin levels after OGTT load in peripheral blood and cerebrospinal fluid of patients with dementia of Alzheimer type. Biol Psychiatry 30: 1219-1228.

Gasparini L, Gouras GK, Wang R, Gross RS, Beal MF, Greengard P, et al. 2001. Stimulation of beta-amyloid precursor protein trafficking by insulin reduces intraneuronal beta-amyloid and requires mitogen-activated protein kinase signaling. J Neurosci 21: 2561-2570. 
Gerozissis K. 2003. Brain insulin: regulation, mechanisms of action and functions. Cell Mol Neurobiol 23: 1-25.

Gerozissis K, Rouch C, Lemierre S, Nicolaidis S, Orosco M. 2001. A potential role of central insulin in learning and memory related to feeding. Cell Mol Neurobiol 21: 389-401.

Gizurarson S, Sigurdsson P, Thorvaldsson T, Gunnarsson E 1995. Technique for administering drugs to the brain and bypassing the blood-brainbarrier. Scand J Lab Anim Sci 22: 273-276.

Gonzalez C, Martin T, Cacho J, Brenas MT, Arroyo T, Garcia-Berrocal B, et al. 1999. Serum zinc, copper, insulin and lipids in Alzheimer's disease epsilon 4 apolipoprotein $\mathrm{E}$ allele carriers. Eur $\mathrm{J}$ Clin Invest 29: 637-642.

Gopinath PG, Gopinath G, Kumar TC. 1978. A Target site of intranasally sprayed substances and their transport across the nasal mucosa: a new insight into the intranasal route of drug-delivery. Curr Ther Res 23: 596-607.

Gregg EW, Yaffe K, Cauley JA, Rolka DB, Blackwell TL, Narayan KM, Cummings SR. 2000. Is diabetes associated with cognitive impairment and cognitive decline among older women? Study of Osteoporotic Fractures Research Group. Arch Intern Med 160: 174-180.

Heitner J, Dickson D. 1997. Diabetics do not have increased Alzheimer-type pathology compared with age-matched control subjects. A retrospective postmortem immunocytochemical and histofluorescent study. Neurology 49: 1306-1311.

Ho L, Qin W, Pompl PN, Xiang Z, Wang J, Zhao Z. et al., 2004. Diet-induced insulin resistance promotes amyloidosis in a transgenic mouse model of Alzheimer's disease. FASEB J 18: 902-904.

Hsieh J, Aimone JB, Kaspar BK, Kuwabara T, Nakashima K, Gage FH. 2004. IGF-I instructs multipotent adult neural progenitor cells to become oligodendrocytes. J Cell Biol. 164: 111-122.

Iwata $\mathrm{N}$, Tsubuki S, Takaki $\mathrm{Y}$, Watanabe $\mathrm{K}$, Sekiguchi M, Hosoki E, et al. 2000. Identification of the major Abeta1-42-degrading catabolic pathway in brain parenchyma: suppression leads to bio-chemical and pathological deposition. Nat Med 6: 143-150.

Jain S, Golde DW, Bailey R, Geffner ME. 1998. Insulin-like growth factor-I resistance. Endocr Rev 19: 625-646.

Juul A. 2003. Serum levels of insulin-like growth factor I and its binding proteins in health and disease. Growth Horm IGF Res 13: 113-170.

Juul A, Main K, Blum WF, Lindholm J, Ranke MB, Skakkebaek NE. 1994. The ratio between serum levels of insulin-like growth factor (IGF)-I and the IGF binding proteins (IGFBP-1, 2 and 3) decreases with age in healthy adults and is increased in acromegalic patients. Clin Endocrinol (Oxf) 41: 85-93.

Kaiyala KJ, Prigeon RL, Kahn SE, Woods SC, Schwartz MW. 2000. Obesity induced by a highfat diet is associated with reduced brain insulin transport in dogs. Diabetes 49: 1525-1533.

Kern W, Born J, Schreiber H, Fehm HL. 1999. Central nervous system effects of intranasally administered insulin during euglycemia in men. Diabetes 48: 557-563.

Kern W, Lieb K, Kerner W, Born J, Fehm HL. 1990. Differential effects of human and pork insulininduced hypoglycemia on neuronal functions in humans. Diabetes 39: 1091-1098.

Kern W, Peters A, Fruehwald-Schultes B, Deininger E, Born J, Fehm HL. 2001. Improving influence of insulin on cognitive functions in humans. Neuroendocrinology 74: 270-280.

Kern W, Peters A, Born J, Fehm HL. 1998. Effects of hyperinsulinemia on sensory processing during an euglycemic clamp in healthy subjects. Exp Clin Endocrinol Diabetes 106: A15-A16. [abstract]

Kilander L, Boberg M, Lithell H. 1993. Peripheral glucose metabolism and insulin sensitivity in Alzheimer's disease. Acta Neurol Scand. 87: 294 298.

Kopf SR, Baratti CM. 1995. The impairment of retention induced by insulin in mice may be mediated by a reduction in central cholinergic activity. Neurobiol Learn Mem 63: 220-228.

Kopf SR, Baratti CM. 1999. Effects of posttraining administration of insulin on retention of a habituation response in mice: participation of a central cholinergic mechanism. Neurobiol Learn Mem 71: 50-61.

Kupila A, Sipila J, Keskinen P, Simell T, Knip M, Pulkki K, et al. 2003. Intranasally administered insulin intended for prevention of type 1 diabetes-a safety study in healthy adults. Diabetes Metab Res Rev 19: 415-420.

Leibson CL, Rocca WA, Hanson VA, Cha R, Kokmen E, O'Brien PC, et al. 1997. Risk of dementia among persons with diabetes mellitus: a 
population-based cohort study. Am J Epidemiol 145: 301-308.

Ling X, Martins RN, Racchi M, Craft S, Helmerhorst E. 2002. Amyloid beta antagonizes insulin promoted secretion of the amyloid beta protein precursor. $\mathrm{J}$ Alzheimers Dis 4: 369-374.

Luchsinger JA, Tang MX, Stern Y, Shea S, Mayeux R. 2001. Diabetes mellitus and risk of Alzheimer's disease and dementia with stroke in a multiethnic cohort. Am J Epidem iol. 154: 635-641.

Messier C. 2003. Diabetes, Alzheimer's disease and apolipoprotein genotype. Exp Gerontol 38: 941946.

Messier C, Awad N, Gagnon M. 2004. The relationships between atherosclerosis, heart disease, type 2 diabetes and dementia. Neurol Res 26: 567-572.

Messier C, Destrade C. 1994. Insulin attenuates scopolamine-induced memory deficits. Psychobiology 22: 16-21.

Messier C, White NM. 1987. Memory improvement by glucose, fructose, and two glucose analogs: a possible effect on peripheral glucose transport. Behav Neural Biol 48: 104-127.

Mielke JG, Taghibiglou C, Liu L, Zhang Y, Jia Z, Adeli $\mathrm{K}$, et al. 2005. A biochemical and functional characterization of diet-induced brain insulin resistance. J Neurochem 93: 1568.

Mustafa A, Lannfelt L, Lilius L, Islam A, Winblad B, Adem A. 1999. Decreased plasma insulin-like growth factor-I level in familial Alzheimer's disease patients carrying the Swedish APP 670/ 671 mutation. Dement Geriatr Cogn Disord 10: 446-451.

Niikura T, Hashimoto Y, Okamoto T, Abe Y, Yasukawa $T$, Kawasumi $M$, et al. 2001. Insulin-like growth factor I (IGF-I) protects cells from apoptosis by Alzheimer's V642I mutant amyloid precursor protein through IGF-I receptor in an IGFbinding protein-sensitive manner. $\mathrm{J}$ Neurosci. 21: 1902-1910.

O'Kusky JR, Ye P, D'Ercole AJ. 2000. Insulin-like growth factor-I promotes neurogenesis and synaptogenesis in the hippocampal dentate gyrus during postnatal development. J Neurosci 2000. 20: 8435-8442.

O'Kusky JR, Ye P, D'Ercole AJ. 2003. Increased expression of insulin-like growth factor I augments the progressive phase of synaptogenesis without preventing synapse elimination in the hypoglossal nucleus. J Comp Neurol 464: 382-391.
Obici S, Feng Z, Karkanias G, Baskin DG, Rossetti L. 2002. Decreasing hypothalamic insulin receptors causes hyperphagia and insulin resistance in rats. Nat Neurosci 56: 566-572.

Orosco M, Gerozissis K, Rouch C, Nicolaidis S. 1995. Feeding-related immunoreactive insulin changes in the PVN-VMH revealed by microdialysis. Brain Res 671: 149-158.

Ott A, Stolk RP, Hofman A, van Harskamp F, Grobbee DE, Breteler MM. 1996. Association of diabetes mellitus and dementia: the Rotterdam Study. Diabetologia 39: 1392-1397.

Ott A, Stolk RP, van Harskamp F, Pols HA, Hofman A, Breteler MM. 1999. Diabetes mellitus and the risk of dementia: The Rotterdam Study. Neurology 53: 1937-1942.

Palovcik RA, Phillips MI, Kappy MS, Raizada MK. 1984. Insulin inhibits pyramidal neurons in hippocampal slices. Brain Res 309: 187-191.

Pardridge WM, Kang YS, Buciak JL, Yang J. 1995. Human insulin receptor monoclonal antibody undergoes high affinity binding to human brain capillaries in vitro and rapid transcytosis through the blood-brain barrier in vivo in the primate. Pharm Res 12: 807-816.

Park, CR; Seeley, RJ; Woods, SC. 1995. ICV insulin increases performance on a passive avoidance task. Soc Neurosci Abstracts 21: 949

Paulus K, Schulz C, Lehnert, H. 2005. Central nervous effects of leptin and insulin on hippocampal leptin and insulin receptor expression following a learning task in Wistar rats. Neuropsychobiology 51: 100106.

Peila R, Rodriguez BL, Launer LJ. 2002. Type 2 diabetes, APOE gene, and the risk for dementia and related pathologies - The Honolulu-Asia Aging Study. Diabetes 51: 1256-1262.

Phiel CJ, Wilson CA, Lee VM, Klein PS. 2003. GSK-3alpha regulates production of Alzheimer's disease amyloid-beta peptides. Nature 423(6938): 435-439.

Poduslo, JF, Curran, GL, Wengenack, TM, Malester, $B$ and Duff, $K$ 2001. Permeability of proteins at the blood-brain barrier in the normal adult mouse and double transgenic mouse model of Alzheimer's disease. Neurobiol Dis 8: 555-567.

Popken GJ, Hodge RD, Ye P, Zhang J, Ng W, O'Kusky JR, D'Ercole AJ, et al. 2004. In vivo effects of insulin-like growth factor-I (IGF-I) on prenatal and early postnatal development of the 
central nervous system. Eur J Neurosci 198: 2056-2068.

Porte D Jr, Baskin DG, Schwartz MW. 2005. Insulin signaling in the central nervous system: a critical role in metabolic homeostasis and disease from $\mathrm{C}$. elegans to humans. Diabetes 545: 1264-1276.

Prince JA, Feuk L, Gu HF, Johansson B, Gatz M, Blennow $K$, et al. 2003. Genetic variation in a haplotype block spanning IDE influences Alzheimer disease. Hum Mutat 22: 363-371.

Refolo LM, Malester B, LaFrancois J, BryantThomas T, Wang R, Tint GS, et al. 2000. Hypercholesterolemia accelerates the Alzheimer's amyloid pathology in a transgenic mouse model. Neurobiol Dis 7: 321-331.

Rollero A, Murialdo G, Fonzi S, Garrone S, Gianelli MV, Gazzerro E, et al. 1998. Relationship between cognitive function, growth hormone and insulinlike growth factor I plasma levels in aged subjects. Neuropsychobiology 38: 73-79.

Rotwein P, Burgess SK, Milbrandt JD, Krause JE. 1998. Differential expression of insulin-like growth factor genes in rat central nervous system. Proc Natl Acad Sci USA 85: 265-269.

Sandhu MS, Heald AH, Gibson JM, Cruickshank JK, Dunger DB, Wareham NJ. 2002. Circulating concentrations of insulin-like growth factor-1 and development of glucose intolerance: a prospective observational study. Lancet 359(9319): 1740-1745.

Schubert M, Gautam D, Surjo D, Ueki K, Baudler S, Schubert D, et al. 2004. Role for neuronal insulin resistance in neurodegenerative diseases. Proc Natl Acad Sci USA 101: 3100-3105.

Schulingkamp RJ, Pagano TC, Hung D, Raffa RB. 2000. Insulin receptors and insulin action in the brain: review and clinical implications. Neurosci Biobehav Rev 24: 855-872.

Schwartz MW, Porte D Jr. 2005. Diabetes, obesity, and the brain. Science 307(5708): 375-379.

Selkoe DJ. 2001. Clearing the brain's amyloid cobwebs. Neuron 32: 177-180.

Shiiki $T$, Ohtsuki S, Kurihara A, Naganuma $H$, Nishimura K, Tachikawa M, et al. 2004. Brain insulin impairs amyloid-beta( $1-40)$ clearance from the brain. J Neurosci 24: 9632-9637.

Soininen H, Puranen M, Helkala EL, Laakso M, Riekkinen PJ. 1992. Diabetes mellitus and brain atrophy: a computed tomography study in an elderly population. Neurobiol Aging 13: 717721.
Spreen O, Strauss E. 1998. A Compendium of Neuropsychological Tests. New York, NY, USA, Oxford University Press.

Strachan MW, Deary IJ, Ewing FM, Frier BM. 1997. Is type II diabetes associated with an increased risk of cognitive dysfunction? A critical review of published studies. Diabetes Care 20: 438-445.

Tamburrano G, Lala A, Locuratolo N, Leonetti F, Sbraccia P, Giaccari A, et al., 1988. Electroencephalography and visually evoked potentials during moderate hypoglycemia. J Clin Endocrinol Metab 66: 1301-1306.

Thorne RG, Pronk GJ, Padmanabhan V, Frey WH 2nd. 2004. Delivery of insulin-like growth factor-I to the rat brain and spinal cord along olfactory and trigeminal pathways following intranasal administration. Neuroscience 127: 481-496.

Vekrellis K, Ye Z, Qiu WQ, Walsh D, Hartley D, Chesneau V, et al. 2000. Neurons regulate extracellular levels of amyloid beta-protein via proteolysis by insulin-degrading enzyme. J Neurosci 20: 1657-1665.

Wan Q, Xiong ZG, Man HY, Ackerley CA, Braunton J, Lu WY, et al. 1997. Recruitment of functional GABA(A) receptors to postsynaptic domains by insulin. Nature 388(6643):686-690.

Watson GS, Peskind ER, Asthana S, Purganan K, Wait C, Chapman D, et al. 2003. Insulin increases CSF Abeta42 levels in normal older adults. Neurology 60: 1899-1903.

Wechsler D. 1981. Wechsler Adult Intelligence Scale-Revised. New York, NY, USA: Harcourt Brace Jovanovich.

Werther GA, Abate M, Hogg A, Cheesman H, Oldfield B, Hards D, et al. 1990. Localization of insulin-like growth factor-I mRNA in rat brain by in situ hybridization-relationship to IGF-I receptors. Mol Endocrinol. 1990 May;4(5): 773-778.

Woods SC, Seeley RJ, Baskin DG, Schwartz MW. 2003. Insulin and the blood-brain barrier. Curr Pharm Des 9: 795-800.

Xie L, Helmerhorst E, Taddei K, Plewright B, Van Bronswijk W, Martins R. 2002. Alzheimer's betaamyloid peptides compete for insulin binding to the insulin receptor. J Neurosci 22: RC221

Zhao L, Teter B, Morihara T, Lim GP, Ambegaokar SS, Ubeda OJ, et al. 2004. Insulin-degrading enzyme as a downstream target of insulin receptor signaling cascade: implications for Alzheimer's disease intervention.J Neurosci 24: 11120-11126. 
Zhao W, Chen H, Xu H, Moore E, Meiri N, Quon $\mathrm{MJ}$, et al., 1999. Brain insulin receptors and spatial memory. Correlated changes in gene expression, tyrosine phosphorylation, and signaling molecules in the hippocampus of water maze trained rats. J Biol Chem 274: 34893-

\section{2.}

Zhong J, Deng J, Phan J, Dlouhy S, Wu H, Yao W, et al. 2005. Insulin-like growth factor-I protects granule neurons from apoptosis and improves ataxia in weaver mice. $J$ Neurosci Res 80: 481990. 

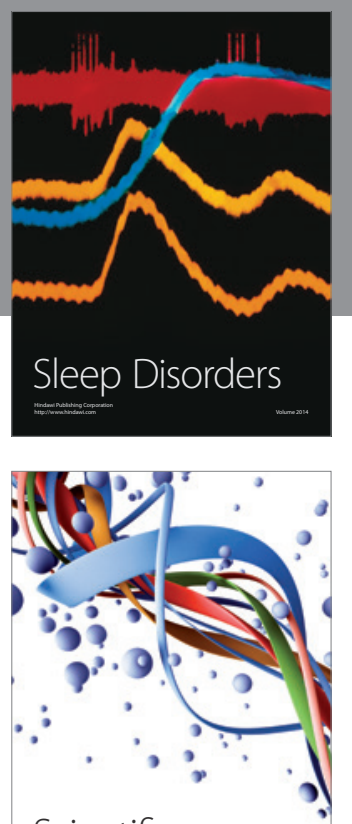

Scientifica
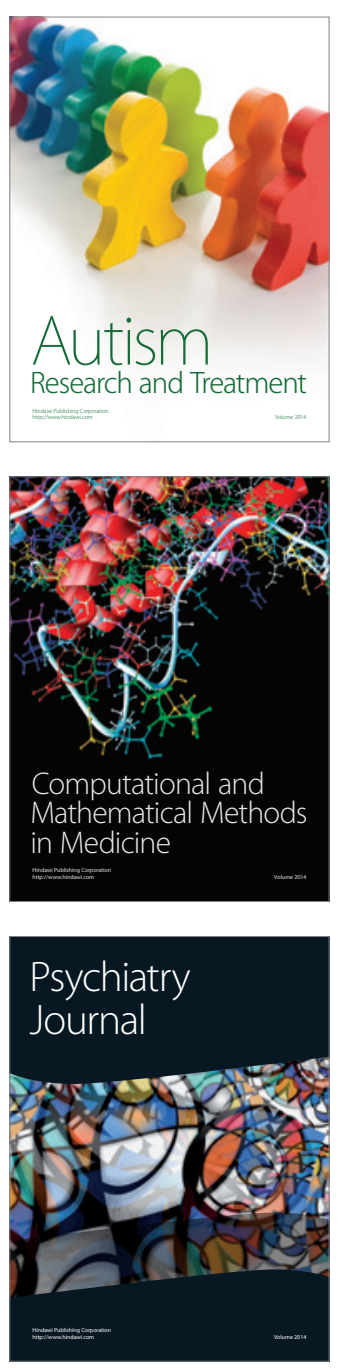
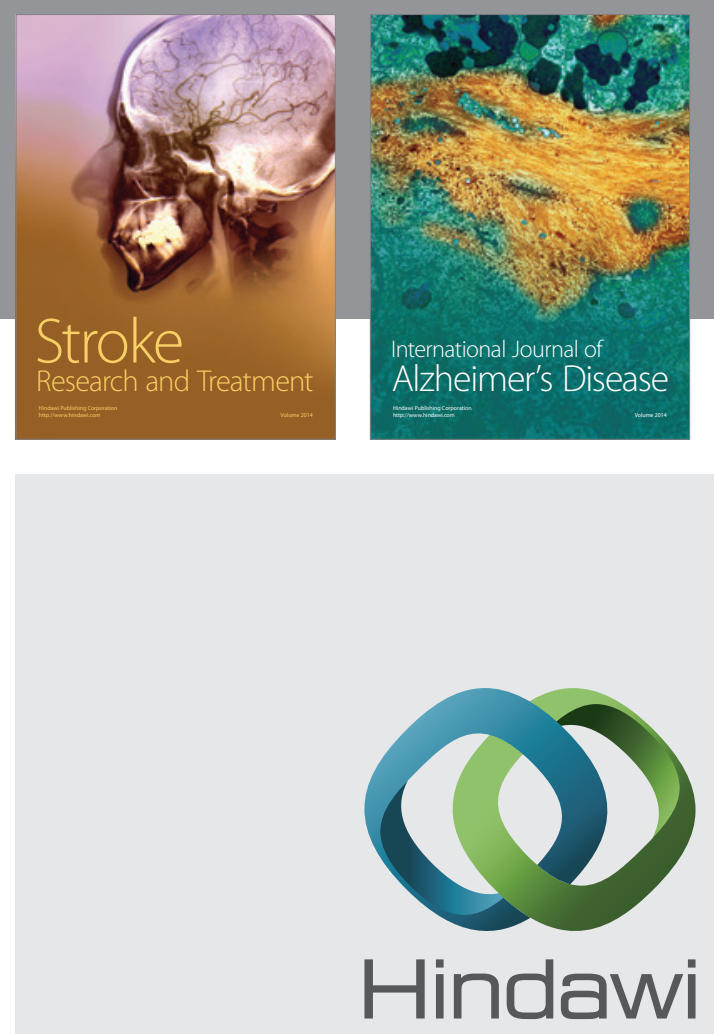

Submit your manuscripts at

http://www.hindawi.com
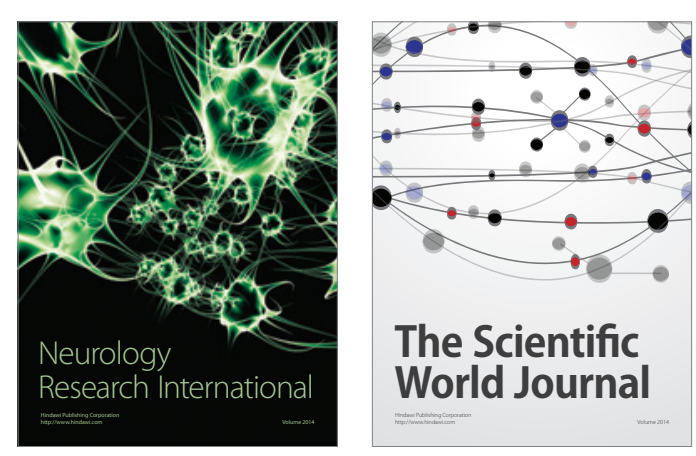

The Scientific World Journal

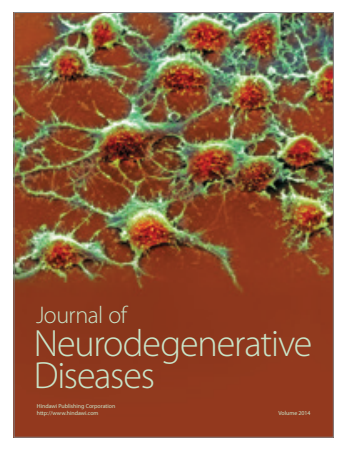

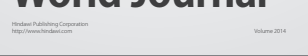

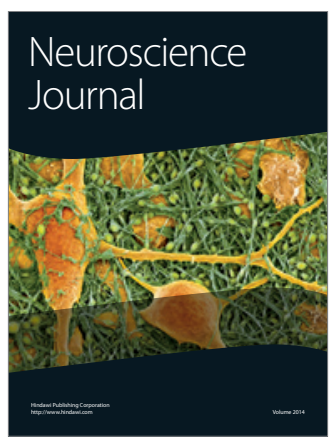

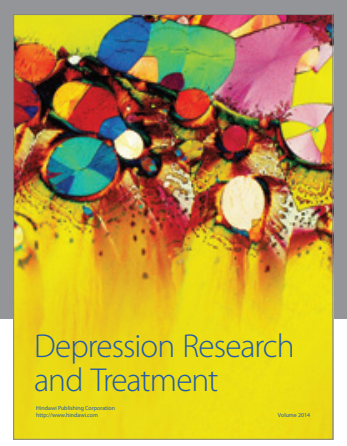
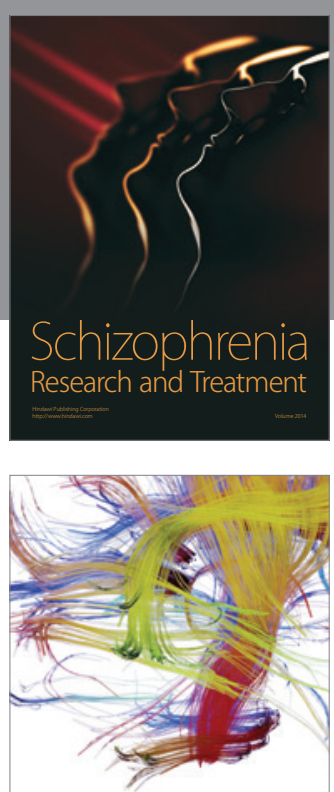

Brain Science

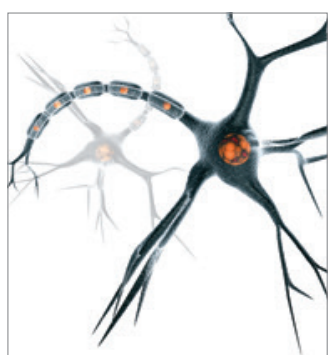

Neural Plasticity
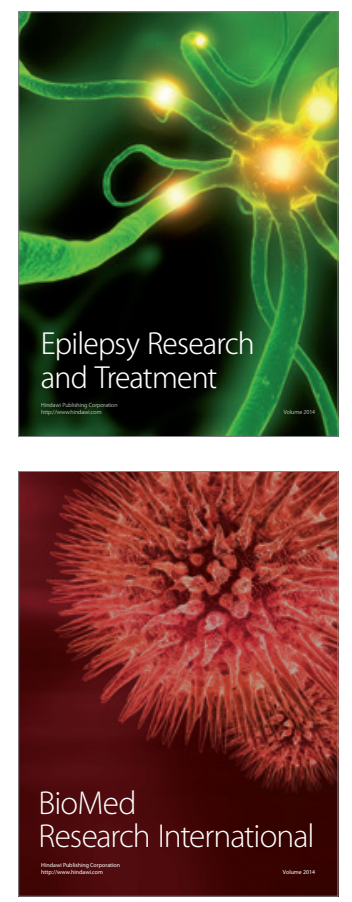

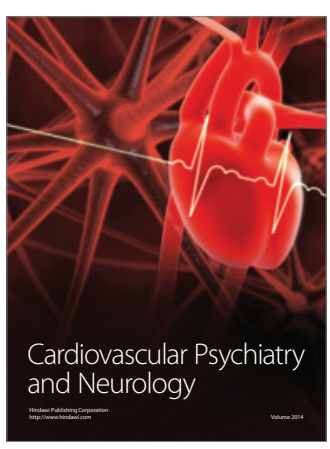

Parkinson's

Disease
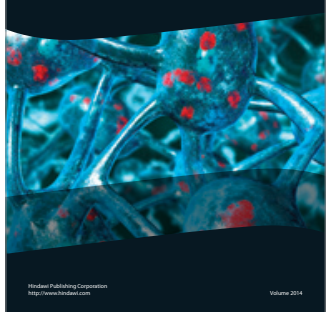